\author{
Iwona Jażdżewska \\ Uniwersytet Łódzki \\ Instytut Geografii Miast i Turyzmu \\ Zakład Geoinformacji \\ iwjazdz@geo.uni.lodz.pl
}

\title{
SKITURING W POLSCE. KTO, JAK I DLACZEGO UPRAWIA TĘ FORMĘ TURYSTYKI KWALIFIKOWANEJ?
}

\begin{abstract}
Abstrakt: W artykule przedstawiono charakterystykę polskich turystów uprawiających skituring. Poszukiwano odpowiedzi na pytania: kto, jak i dlaczego uprawia tę formę turystyki? Jakie doświadczenie mają badani turyści, czy mają świadomość jej niebezpieczeństwa, czy są przygotowani teoretycznie i praktycznie do zagrożenia lawinowego. Porównano cechy społeczne i zachowania turystyczno-rekreacyjne badanych turystów z badaniami przeprowadzonymi przez GUS wśród Polaków w 2012 r.
\end{abstract}

Słowa kluczowe: skituring, zachowania turystyczne, motywy, bezpieczeństwo, Polska.

\section{WPROWADZENIE}

Rozważania naukowe na temat skituringu prowadzone są w różnych aspektach. R. PHILIPP (2010) w pracy pt. Czy narciarstwo wraca do korzeni? Rzecz o filozofii narciarstwa dotyka tego problemu w ujęciu humanistycznym. Zauważa, że „ludzie od starożytności dążyli do doskonałości fizycznej i duchowej" (PHILIPP 2010, s. 80). Na podstawie analizy historyczno-filozoficznej porównuje konsumpcyjne podejście turystów narciarstwa przywyciągowego do podejścia narciarzy tzw. pozawyciągowych. Ci drudzy są bliżsi idei narciarstwa propagowanej $\mathrm{w}$ latach 30 . ubiegłego wieku przez J. Oppenheima, pioniera narciarstwa $\mathrm{w}$ Polsce, który w swoim przewodniku pisał: „Podając niżej opisane szlaki narciarskie Polskich Tatr kierujemy się nadzieją zachęcenia wielu narciarzy do podjęcia trudu wycieczek zimowych w terenie wysokogórskim. Pełna treść nart rozkwita dopiero $\mathrm{w}$ narciarstwie terenowym; w niem to leżą ukryte najcenniejsze dla kultury ludzkiej zalety tego sportu: wytrzymałość, samodzielność, orientacja i zaradczość wobec niebezpieczeństw i trudności" (Oppenheim 1936, za: PHILIPP 2010, s. 41).

W ciągu prawie stulecia turystyka narciarska zmieniła się nie do poznania. Infrastruktura narciarska jest łatwo dostępna i sięga szczytów górskich, a sprzęt narciarski turysty jest coraz lepszej jakości i w zasięgu możliwości finansowych dla przeciętnie zarabiającego Polaka (można go kupić lub wypożyczyć). Dawne wielodniowe trasy „wyryp" narciarskich są dziś "przebiegane" przez skialpinistów w czasie 2-3 godzin, a przeciętny turysta ma dostęp do szczegółowych danych pogodowych w czasie rzeczywistym. Czy można zatem powiedzieć, że to nadal tradycyjna turystyka narciarska? Dlatego bardziej adekwatne wydaje się określenie "skituring”, obco brzmiące i nieznane wielu turystom i miłośnikom gór. Wskazuje ono na nową, rewolucyjną formę turystyki oferującą ekstremalne doznania. Czy jednak różnice w sprzęcie i metodyce poruszania się powodują już, że jest to odmienna dyscyplina? - pyta P. BARTOCHOWSKI (2011).

$\mathrm{W}$ latach 80 . ubiegłego wieku zmiany $\mathrm{w}$ narciarstwie spowodowało ponowne wprowadzenie fok (http://www.national-geographic.pl/) oraz nowych wiązań skiturowych. Foki były znane już w XIX w., a renesans przechodzą obecnie. Nowe pokolenie narciarzy przekonało się, że narty są przydatne nie tylko $\mathrm{w}$ zjeździe, ale wyposażone $\mathrm{w}$ foki ułatwiają też podchodzenie pod górę. Pojedynczy narciarze zaczęli wykorzystywać nowe możliwości techniczne sprzętu. Zauważyli, że rezygnacja z wyciągu na korzyść wysiłku 
własnych mięśni jest nagradzana nowymi przeżyciami, samego zaś zjazdu po nieprzetartych kilometrami terenach wysokogórskich nie da się po prostu z niczym porównać. Z czasem skituring zaczął zyskiwać na popularności. Informacje o tej nietypowej formie aktywności zaczęły pojawiać się w prasie specjalistycznej, a polscy pasjonaci sprowadzali sprzęt z zagranicy. R. Weiss, autor niemieckojęzycznego podręcznika do skituringu $\mathrm{z}$ początku lat 80 ., pisał (za: R. PHILIPP 2010), że skituring dotyka człowieka w całej jego pełni („erfaßt den Menschen in seiner Ganzheit"; WEISS 1983, s. 7).

Celem niniejszego artykułu jest charakterystyka skituringu w Polsce. Posłuży temu prezentacja profilu polskiego turysty skiturowego, poprzez opisanie jego cech demograficznych i społecznych oraz aktywności turystycznej, jej motywów, omówienie wydatków, korzystania z profesjonalnego przewodnictwa turystycznego, a także świadomości niebezpieczeństw, w tym zagrożenia lawinowego w trakcie uprawiania tej formy aktywności. Poznanie zachowań i poglądów narciarzy pozwoli zrozumieć, czym jest skituring i jak dalece odbiega od "wyryp" narciarskich z czasów J. Oppenheima.

\section{DEFINICJA I PRZEGLĄD LITERATURY}

Moda na aktywny wypoczynek oraz znaczna atomizacja form aktywności rekreacyjnej w ostatnich latach przyczynia się do swoistego chaosu terminologicznego w zakresie aktywnych form turystyki, a także sportu i rekreacji. Ważne wydaje się zatem wyjaśnienie na wstępie pojęcia "skituring”.

Skituring jest aktywnością fizyczną uprawianą z wykorzystaniem nart ze specjalnymi wiązaniami umożliwiającymi zarówno zjazdy, jak i podchodzenie pod górę. Dodatkowo istotnym wyposażeniem osoby uprawiającej skituring są tzw. foki, czyli paski z syntetycznego tworzywa zakładane pod narty, pozwalające na podchodzenie pod górę, oraz buty do skituringu (służące zarówno do podejść, jak i zjazdów), a także teleskopowe kijki narciarskie. Skituring oznacza jazdę na nartach w terenie nieoznakowanym, bez infrastruktury narciarskiej. Polega na podchodzeniu pod górę, a następnie zjazdach - po zdjęciu fok oraz po przepięciu wiązań i butów do pozycji zjazdowej (BERBERKA 2015, s. 139).

Wielu problemów nastręcza ustalenie, czy skituring jest rodzajem turystyki, sportu czy rekreacji. W przypadku gdy następuje wyjazd poza stałe miejsce zamieszkania na dłużej niż 24 godziny, aktywność ta może być określana mianem turystyki narciarskiej skiturowej. Ze względu na konieczność przygotowa- nia technicznego i psychofizycznego uczestnika, określana jest często formą turystyki kwalifikowanej. Skituring wymaga bowiem posiadania odpowiedniego sprzętu, umiejętności, kondycji fizycznej oraz doświadczenia i wiedzy (m.in. z zakresu zagrożenia lawinowego i poruszania się $\mathrm{w}$ terenie nieoznakowanym). W takim właśnie ujęciu zagadnienie jest prezentowane w artykule. Warto jednak podkreślić, że w literaturze przedmiotu aktywność ta nazywana jest także mianem aktywnej turystyki sportowej. W przypad$\mathrm{ku}$ podejścia zawodowego, profesjonalnego stanowi dyscyplinę sportu, natomiast gdy jest uprawiana jednorazowo lub w miejscu zamieszkania jest formą rekreacji ruchowej.

Skituring uprawiany jest często w górskich obszarach chronionych. W literaturze naukowej ważnym aspektem badań w kontekście tej formy turystyki było udostępnianie obszarów górskich dla rekreacji i skituringu na obszarach chronionych, np. Kolumbii Brytyjskiej (HARSHAW, SHEPPARD 2004), Szwajcarii (FREULER, HUNZIKER 2007), Tatrzańskiego Parku Narodowego w Polsce (ADAMCZYK 2009) czy ewentualnych skutków środowiskowych wynikających ze schodzenia ze szlaku (BIELAŃSKI 2010, WITKOWSKI i in. 2010).

Jednak najczęściej podejmowane w literaturze zagadnienia dotyczą problematyki bezpieczeństwa narciarzy i zagrożenia lawinowego, na jakie narażone są osoby uprawiający skituring. Zwracają na to uwagę S. HARVEY, B. ZWEIFEL (2008), którzy dokonali analizy wypadków narciarzy będących wynikiem lawin w Szwajcarii w latach 1977-2006, oraz B. VALAT i L. RAVANEL (2013) przypominający o corocznych lawinach, będących zagrożeniem dla turystów-narciarzy (w sezonie 2011-2012 odnotowano we Francji 32 wypadki lawinowe i 14 zgonów). Również Szwedzi prowadzili podobne badania (MAARTENSSON i in. 2013), z których wynika, że w sezonie 2012-2013 aż siedmiu Szwedów zginęło w lawinach, z czego sześciu poza Szwecją. Wyniki badań tego zagadnienia, uzupełnione analizą danych $\mathrm{z}$ dwóch alpinistycznych stron internetowych mediów społecznych (www.bergportal.ch i www. camptocamp.org), opublikowali F. TECHEL i in. (2014).

Przedstawiona literatura $\mathrm{w}$ niewielkim stopniu wykorzystuje badania bezpośrednie z turystami, rzadko prezentując ich profil, poglądy etc. Można je spotkać w pracach poświęconych takim zagadnieniom, jak m.in. konflikty występujące wśród turystów uprawiających skituring i inne formy turystyki zimowej, np. narciarstwo zjazdowe (THAPA, GRAEFE 2004, VASKE, DYAR, TIMMONS 2004), jazdę na skuterach śnieżnych, tzw. snowmobiling (KNOPP, TYGER 1973). Badania społeczne spotyka się natomiast $\mathrm{w}$ pracach dotyczących zachowań i poglądów turystów przebywających na obszarach chronionych (FREULER, HUNZIKER 2007, BIELAŃSKI 2010, WITKOWSKI i in. 2010). 


\section{METODY BADAŃ I DANE ŹRÓDŁOWE}

Pozyskiwanie danych z zakresu turystyki może opierać się na różnych źródłach. Mogą to być źródła wtórne, np. dane urzędów statystycznych, do których można dołączyć inne źródła informacji bezpośredniej, m.in. pomiar ruchu turystycznego na szlaku, oraz pośredniej, np. ewidencja samochodów osobowych parkujących w pobliżu atrakcyjnych turystycznie obiektów. Bardziej pogłębioną wiedzę o turystach uzyskuje się poprzez badania społeczne. W niniejszej pracy, w której podmiotem badań byli aktywni narciarze uprawiający skituring w Polscel, wykorzystano następujące metody i źródła danych:

- obserwacje tras narciarzy poza szlakami, także pośrednie, na podstawie śladów nart na śniegu;

- badania społeczne przeprowadzone z turystami;

- wyniki badań GUS dotyczące aktywności sportowej Polaków (ich wykształceniu);

- wyniki badań firmy Sedlak \& Sedlak, która w oparciu o własną metodologię publikuje raporty na temat wynagrodzeń (www.wynagro dzenia.pl);

- wyniki badań innych autorów.

Obserwacje bezpośrednie przeprowadzono na górskich szlakach turystycznych Tatrzańskiego Parku Narodowego, które uznawane są za najpopularniejsze wśród narciarzy: Dolina Chochołowska, Dolina Kościeliska, Dolina Kondratowa, Hala Gąsiennicowa, Dolina Pięciu Stawów Polskich, Dolina Rybiego Potoku. Ponadto dokonano obserwacji śladów nart $\mathrm{w}$ wymienionych dolinach (wraz z ich górnymi piętrami i odgałęzieniami). Wyjątkiem była Dolina Kościeliska, gdzie przeprowadzono obserwacje tylko niektórych szlaków, głównie w masywie Ornaku. Ze względu na ochronę przyrody nie odwiedzono również Doliny Waksmundzkiej i Doliny Pańszczycy. Ślady nart pozostawione przez turystów ułatwiają wskazanie najbardziej uczęszczanych miejsc, jak też dostarczają informacji o poziomie zaawansowania i technice jazdy oraz umożliwiają ocenę umiejętności narciarskich. Ich obserwacja była prowadzona na wstępie badań i pozwoliła na stwierdzenie, że w polskich Tatrach są aktywni narciarze uprawiający skituring, zatem można przystąpić do kolejnych etapów badania.

W badaniach społecznych można wyróżnić cztery podstawowe metody zbierania danych: techniki obserwacyjne, badania sondażowe, wtórną analizę danych i badania jakościowe. $W$ pracy badawczej na potrzeby niniejszego artykułu wykorzystano trzy pierwsze. Obserwację uczestniczącą, w której badacz staje się członkiem ankietowanej grupy. Obserwacja może być jawna lub niejawna; wykorzystano pierwszą $\mathrm{z}$ wymienionych - nie ukrywano celu obserwacji, ani swojej tożsamości. Przeprowadzono badania pilotażowe na forum www.skitury.fora.pl, a następnie badania sondażowe z wykorzystaniem kwestionariusza. Dotarcie do osób uprawiających ten typ turystyki nie jest łatwe. Badania sondażowe były trudne do przeprowadzenia ze względu na środowisko przyrodnicze (geograficzne) i porę roku. Turyści poszukują wrażeń z dala od zgiełku miast, często są $\mathrm{w}$ ruchu, a nie powinno się zakłócać wypoczynku i zatrzymywać ich w celu wypełnienia ankiety. $Z$ tego też powodu niemożliwe było sporządzenie listy osób do losowania próby. Wcześniejsza znajomość populacji pozwoliła na dobór jednostek do próby z kilku źródeł. Ankietowano zarówno turystów spotkanych przypadkowo na szlaku lub w schronisku, jak i grupy zorganizowane pod opieką przewodnika lub instruktora narciarstwa wysokogórskiego. Przeprowadzono badania ankietowe z aktywnymi narciarzami i turystami na terenie Tatrzańskiego Parku Narodowego (59 osób), wykorzystano również forum internetowe skiturowe, co pozwoliło na dotarcie do większej grupy narciarzy (92 osoby). Jest to forum, które istnieje od 01.03.2006 r. i liczy 1853 zarejestrowanych użytkowników oraz 39750 napisanych wiadomości (stan z 02.09.2011). Forum skiturowe określane jest jako "nieformalny klub skiturowy” (BARTOCHOWSKI 2011). Badania ankietowe przeprowadzono w kwietniu 2011 r., czyli w szczycie sezonu skiturowego. Analizie poddano 151 osób (18 kobiet i 133 mężczyzn), co może stanowić około $5-10 \%$ osób czynnie uprawiających skituring w Polsce w 2011 r. Uznano, że zebrane wyniki są wystarczające do wnioskowania na temat próby, dają też pewien obraz całej populacji.

\section{WYNIKI BADAŃ}

Czym jest skituring? Nową formą turystyki aktywnej czy powrotem do korzeni narciarstwa? Kto ją uprawia? Jakimi motywami kieruje się i czy ma świadomość niebezpieczeństwa będąc na trasie $\mathrm{w}$ górach? Czy nie zagraża środowisku przyrodniczemu, szczególnie na obszarach chronionych? Czy nie zakłóca wypoczynku innym turystom? To tylko część pytań, na które odpowiadając możemy zbudować profil turysty uprawiającego skituring.

Przypomnieć należy, że analiza profilu turysty skiturowego obejmowała na wstępie:

- cechy demograficzne i społeczne,

- pochodzenie terytorialne,

- własną ocenę stanu zdrowia,

- aktywność turystyczną i rekreacyjną.

Rola skituringu $\mathrm{w}$ życiu respondentów była badana $z$ wykorzystaniem analizy ich odpowiedzi na pytania: jak długo tę formę aktywności fizycznej uprawiają, z kim, skąd dowiedzieli się o skituringu, jakie są 
motywy jej uprawiania, a także czy uczestniczą w zawodach sportowych? Świadomość niebezpieczeństw i zagrożenia lawinowego $\mathrm{w}$ trakcie uprawiania tej formy aktywności, ocena własnej wiedzy i umiejętności w zakresie bezpieczeństwa w górach była ostatnią poruszaną kwestią w badaniu.

\subsection{CHARAKTERYSTYKA RESPONDENTÓW}

Odpowiedź na pytanie: kto uprawia skituring, daje analiza ankiet $(\mathrm{N}=151)$ i obserwacja uczestnicząca w terenie. Wśród badanych przeważający jest udział mężczyzn (88\%) w stosunku do liczby kobiet (12\%), co potwierdzają obserwacje terenowe. W strukturze wiekowej około $90 \%$ stanowiły osoby poniżej 45 . roku życia i mające więcej niż 18 lat. Dominowała grupa w wieku 26-35 lat (40\%), następnie 36-45 lat (26\%) oraz osoby majace od 19 do 25 lat (25\%). W badanej populacji mniej niż $10 \%$ stanowią turyści po 45 . roku życia, a tylko jedna osoba przekroczyła wiek emerytalny. Zastanawiający jest brak niepełnoletnich $\mathrm{w}$ badanej strukturze, choć nie ograniczano doboru respondentów z uwagi na wiek. Powyższe wyniki wskazują, że skituring to forma aktywności najbardziej odpowiadająca osobom młodym, ale dorosłym i w średnim wieku, co można tłumaczyć wysokimi wymaganiami fizycznymi wobec skiturowców (niespełnianymi przez osoby starsze), jak też koniecznością posiadania dostatecznego doświadczenia górskiego. Ankietowani turyści legitymowali się ponadprzeciętną dla Polski strukturą wykształcenia, bowiem aż 74\% miało wyższe (55\% magisterskie i $19 \%$ licencjackie), a pozostali średnie i policealne (26\%). Według NSP w 2011 r. wykształcenie wyższe deklarowało 16,8\% Polaków, a średnie i policealne $34,1 \%$.

Aktywność zawodowa badanych była bardzo zróżnicowana. Co czwarty był informatykiem lub inżynierem, a co dziesiąty studentem. Byli też handlowcy, finansiści, urzędnicy, nauczyciele, lekarze i przedstawiciele innych zawodów. Można przypuszczać, że większość respondentów wykonywała intensywną pracę umysłową.

Z aktywnością zawodową związane są dochody. Uprawianie turystyki wymaga przeznaczenia określonej kwoty na specjalistyczny ekwipunek, której brak może być barierą uprawiania tej formy rekreacji ruchowej. Na pytanie: jak określasz w skali 1-10 (bardzo zła - bardzo dobra) swoją sytuację finansową? - uzyskano zróżnicowane odpowiedzi (rys. 1). Badani określali swoją sytuację finansową jako nieco wyższą niż przeciętną (mediana i dominanta wynosiły 6 pkt. na 10 możliwych). Może na to wpływać wykonywany zawód respondentów. Porównanie w Polsce przeciętnych zarobków (publikowanych na www.wynagro dzenia.pl; 09.2011) informatyków, lekarzy, kadry me- nadżerskiej, inżynierów $\mathrm{z}$ innymi grupami zawodowymi potwierdza, że plasują się one powyżej mediany krajowej. Można stwierdzić, że wśród ankietowanych znaczny udział mają osoby o dochodach przekraczających średnią krajowa, ale liczna jest grupa o dochodach niższych (nauczyciele, zatrudnieni w handlu oraz administracji). Nie występują natomiast wśród nich osoby o skrajnie niskich dochodach, co można tłumaczyć tym, że koszty uprawiania skituringu są na tyle duże, że stanowią barierę dla najmniej zamożnych grup społecznych. Nie jest to jednak dyscyplina elitarna dostępna tylko dla najbogatszych (BARTOCHOWSKI 2011).

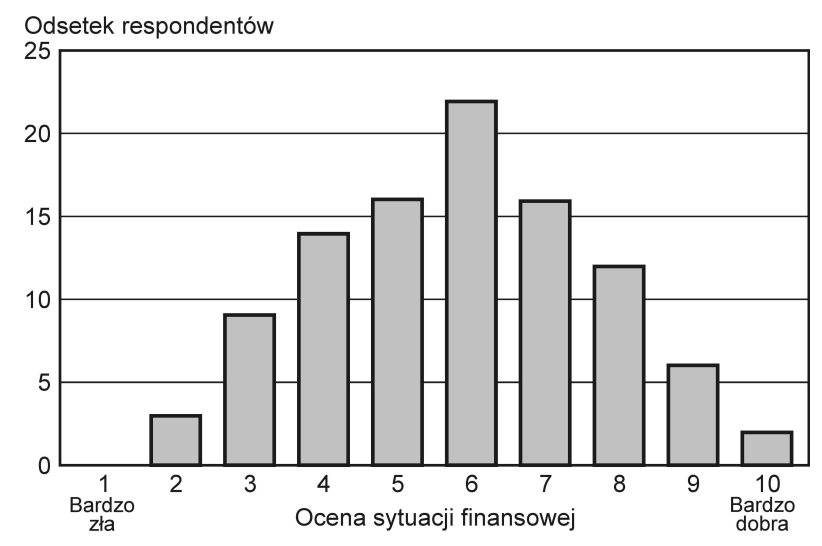

Rys. 1. Ankietowani skiturowcy według oceny własnej sytuacji finansowej w skali 1-10 (bardzo zła - bardzo dobra)

Źródło rys. 1-8: P. BARTOCHOWSKI (2011) zmodyfikowane

Tab. 1. Wielkość miejscowości będących miejscem zamieszkania badanych osób uprawiających skituring

\begin{tabular}{|l|c|c|}
\hline $\begin{array}{c}\text { Wielkość miejscowości } \\
\text { zamieszkania }\end{array}$ & $\begin{array}{c}\text { Odsetek } \\
\text { respondentów }\end{array}$ & $\begin{array}{c}\% \\
\text { kumulowany }\end{array}$ \\
\hline $\begin{array}{l}\text { Miasto powyżej 500 tys. } \\
\text { osób }\end{array}$ & 40 & 40 \\
\hline Miasto od 201 do 500 tys. & 6 & 46 \\
\hline Miasto od 101 do 200 tys. & 8 & 54 \\
\hline Miasto od 51 do 100 tys. & 6 & 60 \\
\hline Miasto do 50 tys. & 21 & 81 \\
\hline Wieś & 19 & 100 \\
\hline
\end{tabular}

Źródło: P. BARTOCHOWSKI (2011), zmodyfikowane.

Skąd pochodzili badani turyści? Wszyscy byli Polakami. Większość (81\%) mieszkała w miastach różnej wielkości (tab. 1), a pozostali (19\%) na terenach wiejskich. Ponad połowa $\mathrm{z}$ nich (54\%) pochodziła $\mathrm{z}$ dużych miast liczących ponad 100 tys. mieszkańców (głównie z Krakowa, w mniejszym udziale z Warszawy oraz Łodzi, Wrocławia, Poznania). Co piąty turysta przyjeżdżał z małego lub średniego miasta, ale na tak wysoki odsetek ma wpływ Zakopane, w którym mieszka wielu aktywnych narciarzy. Osoby deklarujące pochodzenie wiejskie (19\%) nie były rolnikami; większość badanych z tej grupy wskazywała na miej- 
scowości podmiejskie w pobliżu dużych aglomeracji, a także wsie podhalańskie, takie jak Poronin czy Małe Ciche.

Region zamieszkania respondentów był związany z odległością od Tatrzańskiego Parku Narodowego. Największą grupę stanowili mieszkańcy województwa małopolskiego (41\%), na terenie którego znajduje się TPN, oraz sąsiadującego z nim województwa śląskiego (26\%), będącego największym skupiskiem ludności miejskiej na terenie Polski. Z pozostałych województw należy wymienić województwo mazowieckie (8\%), łódzkie, dolnośląskie (po 5\%), wielkopolskie (4\%) i, sąsiadujące z małopolskim, podkarpackie (2\%); pozostałe województwa wskazywały jedynie pojedyncze osoby. Wśród badanych nie znalazł się żaden mieszkaniec województw: zachodniopomorskiego, warmińsko-mazurskiego ani podlaskiego.

\subsection{AKTYWNOŚĆ TURYSTYCZNA I REKREACYJNA BADANYCH}

Zagadnienia dotyczące aktywności turystycznej wiążą się ze stanem zdrowia turysty. Pytania o ocenę zdrowia wynikały z wysokiego poziomu wymagań fizycznych, jakie stawia skituring. $Z$ tego powodu ważne było poznanie odpowiedzi na pytanie o świadomość stanu własnego zdrowia (rys. 2). Większość badanych wskazywała na bardzo dobry stan zdrowia, 76\% osób oceniło stan zdrowia na 8 pkt. i więcej; mediana, jak i dominanta odpowiedzi wynosiła 8 pkt. na 10 możliwych.

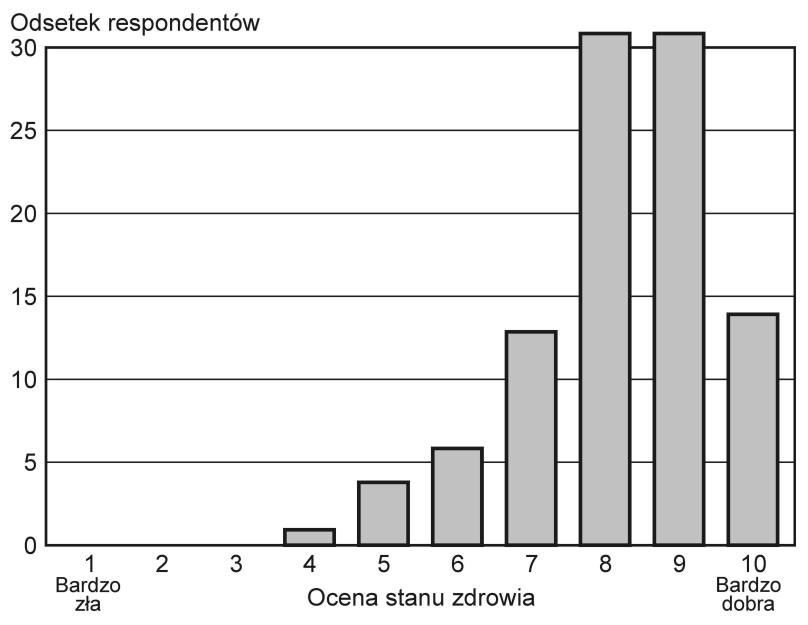

Rys. 2. Ankietowani uprawiający skituring według oceny stanu własnego zdrowia w skali 1-10 (bardzo zła - bardzo dobra)

Dobry stan zdrowia uprawiających skituring może być związany $\mathrm{z}$ ich aktywnością fizyczną $\mathrm{w}$ ciągu całego roku. Jest to ważne, gdyż respondenci w większości deklarowali zawody związane z małą aktywnością ruchową, np. informatycy, lekarze. Rekreacja ruchowa okazała się bardzo popularna wśród badanych i prawie każdy z nich wskazał co najmniej kilka uprawianych dyscyplin. Tak wysoki poziom aktywności skiturowców wydaje się uzasadniony, biorąc pod uwagę wymagania fizyczne, jakie stawia ta forma aktywności przed osobą chcącą ją uprawiać.

Większość badanych uprawiało regularnie rekreację ruchową. Częstotliwość jej uprawiania była dość zróżnicowana. Prawie co dziesiąty respondent ćwiczy1 codziennie (9\%) - 4-6 razy w tygodniu ćwiczyło 15\%, ponad połowa ankietowanych 2-3 razy w tygodniu. Raz w tygodniu lub rzadziej rekreację ruchową uprawiała $1 / 4$ badanych.

Na tle społeczeństwa polskiego ankietowani wykazują niezwykle dużą aktywność ruchową. Nie tylko każdy z nich przyznaje, że regularnie uprawia rekreację ruchową, ale większość robi to bardzo często. Dla porównania, według raportu GUS z 2012 r. obejmującego badania aktywności sportowej w okresie od 1.10 . 2011 r. do 30.09.2012 r., około 50\% badanych Polaków uczestniczyło w zajęciach sportowych lub rekreacyjnych, ale regularnie (czyli przynajmniej jeden raz w tygodniu) ćwiczyło 20,3\% członków gospodarstw domowych (http:/ / stat.gov.pl/).

Można zatem stwierdzić, że sport i rekreacja stanowią ważne obszary życia badanych, na które poświęcają znaczną część wolnego czasu.

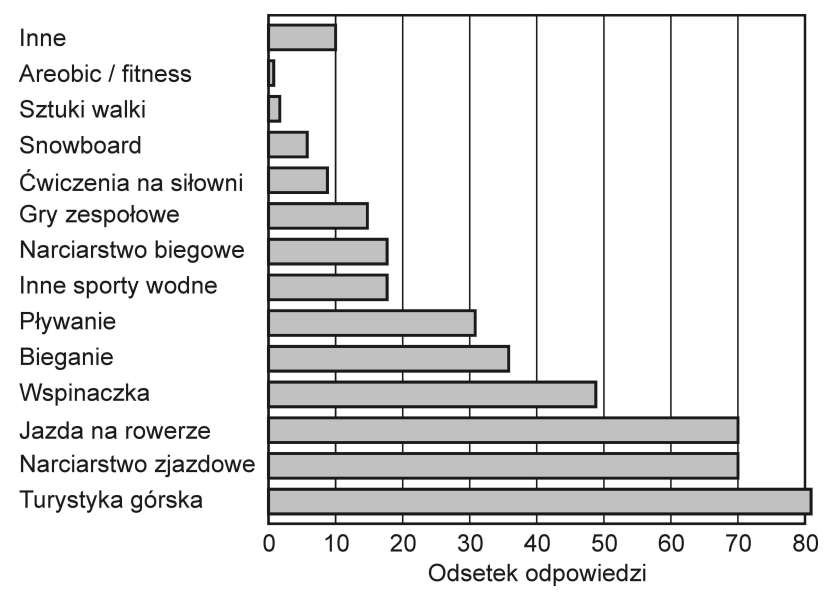

Rys. 3. Struktura uprawianych dyscyplin sportowych przez respondentów (możliwe było wskazanie kilku odpowiedzi)

Analizując uprawiane przez respondentów dyscypliny sportowe można było zauważyć kilka tendencji (rys. 3). Bardzo duże znaczenie miała aktywność związana z górami (turystyka górska - 81\%, narciarstwo zjazdowe - 70\%, wspinanie - 49\%). Dużą popularnością cieszyły się dyscypliny wytrzymałościowe (jazda na rowerze $70 \%$, bieganie $36 \%$, pływanie $31 \%$ ). Niewielki był udział ćwiczeń siłowych oraz fitness, co wskazuje na preferencje podejmowania aktywności ruchowej na świeżym powietrzu. Spośród dyscyplin 
sportów zimowych stosunkowo rzadko w porównaniu $\mathrm{z}$ narciarstwem zjazdowym wybierano narciarstwo biegowe i snowboard. Można przypuszczać, że zjazd na nartach jest formą przygotowania do skituringu dla większości respondentów.

Ankietowana grupa różniła się od badanych przez GUS Polaków w latach 2011/2012. „Najpopularniejszymi zajęciami sportowo-rekreacyjnymi wśród Polaków były jazda na rowerze i pływanie. Aktywność w pierwszej z form podjęło $66,0 \%$ osób, drugą wybrało 39,9\% zbiorowości. Poza tymi dwoma głównymi formami aktywności mężczyźni preferowali grę $\mathrm{w}$ piłkę nożną $(36,7 \%)$, siatkową $(14,3 \%)$ i koszykową $(10,3 \%)$ oraz wędkarstwo (13,3\%). Kobiety najczęściej decydowały się na aerobik, fitness, jogę i gimnastykę (19,5\%), taniec $(16,5 \%)$, jogging, nordic walking $(15,8 \%)$ oraz grę w piłkę siatkową (13,3\%)". Sporty zimowe nie należały do ulubionych form aktywności Polaków w tym czasie, tak jak to miało miejsce wśród badanych na potrzeby niniejszej pracy osób uprawiających skituring.

\subsection{SKITURING W ŻYCIU BADANYCH}

Odpowiedź na pytanie: „Jakie doświadczenie mają ankietowani w uprawianiu tej formy aktywności fizycznej?", pozwoli na lepsze poznanie nie tylko badanej zbiorowości, ale również może posłużyć do oszacowania czasu jej uprawiania w Polsce. Połowa ankietowanych (54\%) wskazywała na niedługi (poniżej 3 lat) staż uprawiania skituringu, dość liczna (11\%) była grupa początkujących. Prawie co piąty ankietowany mógł pochwalić się 4-5-letnim stażem, a co dziesiąty wskazywał na 6-8 lat doświadczenia lub też ponad 13-letni staż w tej dyscyplinie, 8\% respondentów uprawiało skituring 9 do 12 lat. Prezentowane wyniki badań mogą być dowodem na dynamiczny wzrost popularności skituringu. Wskazują również, że najszybszy rozwój tej dyscypliny przypadał na lata 2008-2009.

Tab. 2. Staż uprawiania skituringu przez badanych

\begin{tabular}{|l|c|c|}
\hline \multicolumn{1}{|c|}{ Staż } & $\begin{array}{c}\text { Udział } \\
\text { respondentów }\end{array}$ & $\begin{array}{c}\% \\
\text { kumulowany }\end{array}$ \\
\hline Pierwszy sezon & 11 & 11 \\
\hline 2-3 lata & 43 & 54 \\
\hline 4-5 lat & 18 & 72 \\
\hline 6-8 lat & 10 & 82 \\
\hline 9-12 lat & 8 & 90 \\
\hline 13 i dłużej & 10 & 100 \\
\hline
\end{tabular}

Źródło: P. BARTOCHOWSKI (2011), zmodyfikowane.

Skąd ankietowani dowiedzieli się o skituringu? Ponad połowa badanych (52\%) usłyszała o nim od znajomych, prawie $1 / 3$ (31\%) widziała skiturowców na szlaku. Zauważalny jest również udział Internetu
(17\%). Pozostałe źródła informacji, w szczególności media tradycyjne, miały znikomy wpływ na uzyskanie przez badanych wiedzy o tej formie aktywności. Świadczy to o tym, że nadal jest ona niszowa, ale krąg zainteresowanych poszerza się. Większość osób uprawiających skituring informuje i zachęca swoich znajomych do jego uprawnia. Podstawowe informacje przekazywane są też często przypadkowym osobom spotkanym na szlaku i zainteresowanych tym nieznanym im wcześniej sposobem wypoczynku zimą.

Skituring, nadal dość mało popularna forma turystyki kwalifikowanej, nieuprawiana jest w dużych grupach w formie masowych wycieczek zorganizowanych. Jedyna komercyjna forma to jedno- lub kilkudniowe wycieczki pod opieką przewodnika górskiego lub też kursy skiturowe dla początkujących; nie były one jednak popularne wśród badanych (rys. 4). Zdecydowana większość turystów (75\%) „wędrowała na nartach" ze znajomymi. Wielu z nich przyznawało się również do samotnych wędrówek, co wydaje się być kontrowersyjne w kontekście wspomnianego już problemu bezpieczeństwa w górach zimą. Niewielki procent turystów zabierało na wycieczki członków rodziny. Związane jest to z dużymi wymaganiami zarówno fizycznymi, jak i w kwestii umiejętności technicznych, jakie stawia skituring. W połączeniu z dość dużym stopniem ryzyka należy stwierdzić, że nieodpowiedzialne jest zabieranie na takie „wędrówki" rodzin z dziećmi (rys. 4).

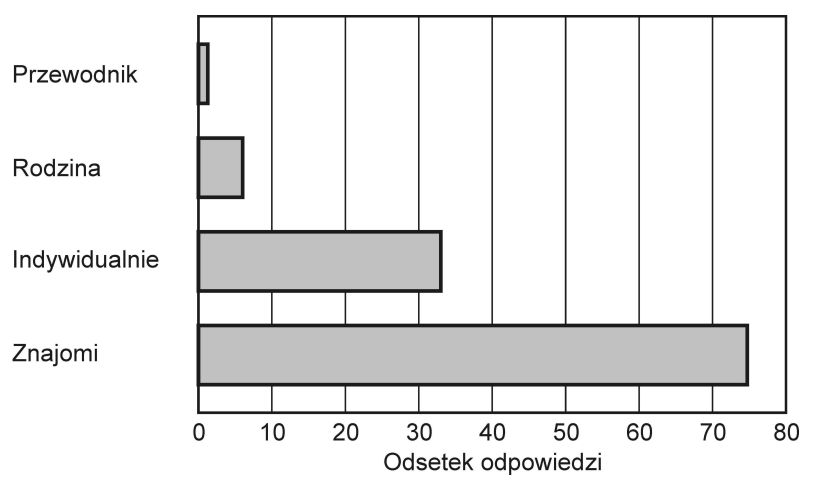

Rys. 4. Osoby towarzyszące ankietowanym skiturowcom na szlaku (możliwe było wskazanie kilku odpowiedzi)

Jakimi motywami kierowały się osoby uprawiające tę formę aktywności, wymagającą dobrej sprawności fizycznej i wysokich umiejętności jazdy na nartach? Najważniejszym motywem uprawiania skituringu wśród badanych była chęć aktywnego wypoczynku i relaksu (71\%). Na wycieczkach skiturowych ankietowani spędzali urlopy i weekendy, w ten sposób relaksując się po pracy. Nieco mniej ważna okazała się potrzeba dbania o zdrowie i kondycję fizyczną (49\%). W tym miejscu warto przypomnieć (rys. 2), że respondenci doskonale oceniali swój stan zdrowia, a mimo to 
nie negowali dalszej potrzeby dbania o kondycję fizyczną. Inne motywy zachęcające badanych do uprawiania skituringu to możliwość sprawdzenia własnych umiejętności (31\%) oraz doznania nowych wrażeń (19\%). Z uwagi na to, że skituring jest mało popularną dyscypliną, zaliczaną często także do sportów ekstremalnych, trudno się dziwić tym odpowiedziom. $Z$ innych wskazywanych motywów szczególnie widoczne były dwa. Pierwszy, charakteryzujący narciarzy zjazdowych, to możliwość zjazdów poza wyznaczonymi trasami, w głębokim puchu i na trudnym terenie. Drugim motywem, o którym mówili głównie turyści piesi, było traktowanie skituringu jako wygodnego sposobu poruszania się $\mathrm{w}$ górach $\mathrm{w}$ sezonie $\mathrm{zi}-$ mowym.

Odpowiedzi badanych wskazują, że ich motywy uprawiania skituringu są odmienne od motywów większości Polaków skłaniających ich do uprawiania sportu, gdyż z badań GUS z 2012 r. wynika, że głównym motywem uczestnictwa Polaków w sporcie i rekreacji ruchowej była przyjemność i rozrywka, którymi kierowało się $2 / 3$ badanych, a na chęć utrzymania kondycji fizycznej oraz zachowania właściwej sylwetki wskazało $15,5 \%$ mężczyzn i $20 \%$ kobiet. Co dziesiąty Polak uczestniczył w sporcie i rekreacji „dla zdrowia" (rys. 5).

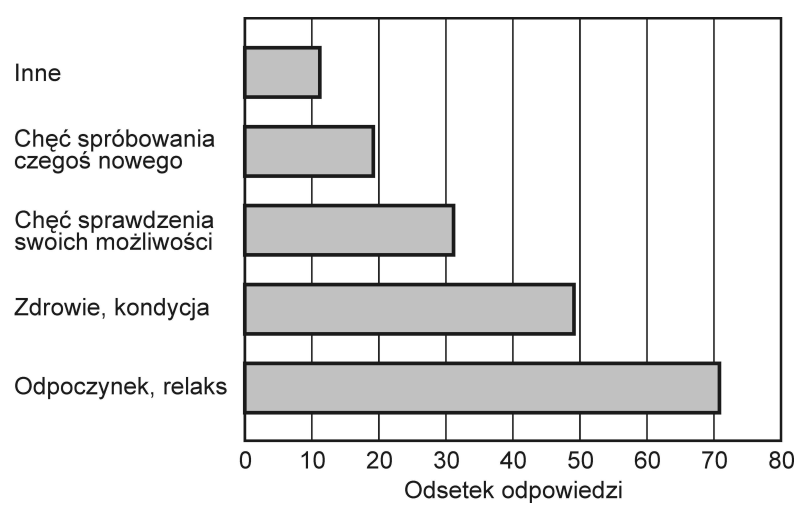

Rys. 5. Motywy uprawiania skituringu przez respondentów (możliwe było wskazanie kilku odpowiedzi)

Część ankietowanych z dłuższym stażem w uprawianiu skituringu brała udział $\mathrm{w}$ zawodach skialpinistycznych. Wśród startujących regularnie $\mathrm{w}$ zawodach (4\% badanych) dominują osoby z 4-8-letnim stażem, większość to zawodnicy wyczynowi, trenujący prawie codziennie i wyposażeni w sprzęt specjalnie przystosowany do wyścigów (możliwie najlżejsze narty, buty i akcesoria zgodne $z$ normami stawianymi przez Komisję Narciarstwa Wysokogórskiego PZA). Osoby startujące okazjonalnie rekrutują się spośród wszystkich grup, ale najwięcej z nich ma staż dłuższy niż 6 lat, są to narciarze o większym doświadczeniu, a więc zwykle posiadający większe umiejętności.
W przeważającej części są to amatorzy, którzy mogą sprawdzić się np. w zawodach Amatorskiego Pucharu Polski w Skialpinizmie, $\mathrm{z}$ łatwiejszymi technicznie trasami, a zawodnicy nie muszą spełniać rygorystycznych norm dotyczących sprzętu ani posiadać profesjonalnej licencji. Zawody skialpinistyczne wymagają doskonałego przygotowania kondycyjnego, nie bez znaczenia jest też praktyka w używaniu sprzętu, a zwłaszcza szybkość zmian konfiguracji „podejście/ zjazd". Tym samym warto odnotować fakt nawet niewielkiego udziału osób początkujących w zawodach, którzy muszą zmierzyć się z licznymi trudnościami.

Do uprawiania skituringu niezbędny jest profesjonalny sprzęt, odmienny od tego, jakiego używa się w narciarstwie zjazdowym. Oprócz odpowiedniego ubrania, gogli lub okularów przeciwsłonecznych, kas$\mathrm{ku}$, plecaka potrzebne są narty (różnią się od zjazdowych wytrzymałością, są lżejsze, mają zaczepy na "fo$\mathrm{ki}^{\prime \prime} \mathrm{i}$ czasem dziurkę $\mathrm{w}$ dziobie) $\mathrm{z}$ odpowiednimi wiązaniami (to specjalne wiązania, które mają ruchomą piętę i umożliwiają podchodzenie, a do zjazdu można je zablokować i wtedy działają jak zwykłe wiązania zjazdowe), foki, detektor lawinowy, sondę i łopatkę. $Z$ tego powodu koszty wyprawy mogą być wyższe niż osób uprawiających rekreacyjne narciarstwo zjazdowe. Jak wysokie są to koszty i czy istnieje związek ponoszonych kosztów z sytuacją finansową respondentów ukazuje rys. 6.

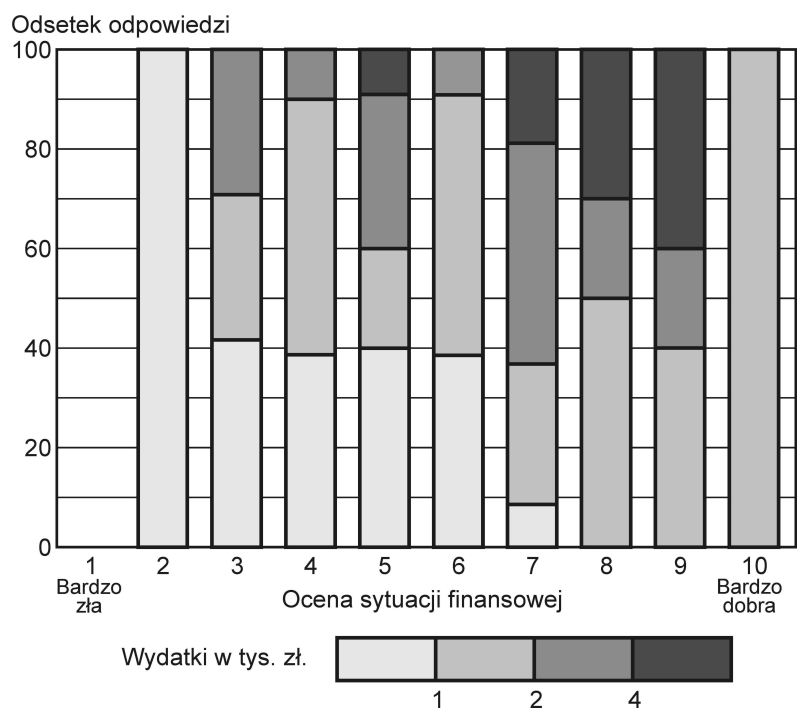

Rys. 6. Wydatki na uprawianie skituringu a sytuacja finansowa badanych

Można wnioskować, że bardziej zamożni skiturowcy wydawali więcej na uprawianie tej formy aktywności - byli to respondenci oceniający swoją sytuację finansową na poziomie od 7 do 9 pkt. Im gorsza sytuacja finansowa, tym mniej wydawano. Dla najmniej zamożnych był to koszt do 1000 zł na sezon, a wśród osób o przeciętnej zamożności wydatki były zróż- 
nicowane. Trzy osoby wskazujące najwyższy pułap swojej sytuacji finansowej (10 pkt.) wydawały poniżej 2 tys. zł w sezonie.

Jakie dodatkowe koszty ponoszą osoby uprawiające skituring? Jest to m.in. korzystanie $z$ usług doświadczonego przewodnika. Niektórzy respondenci regularnie uczestniczyli w kilkudniowych wycieczkach narciarskich w Tatrach polskich i słowackich, a także w Alpach. Właśnie te ostatnie są poważnym źródłem zarobku dla przewodników. Specyfika poruszania się $\mathrm{w}$ górach $\mathrm{z}$ lodowcami jest bowiem inna, a trudności organizacyjne takiego wyjazdu są większe. To sprawia, że najlepsi przewodnicy mają grupę stałych klientów, którzy co roku odwiedzają z nimi alpejskie szczyty i przełęcze. Spośród badanych jedynie osoby najbardziej doświadczone nie korzystały z usług przewodnika (rys. 7).

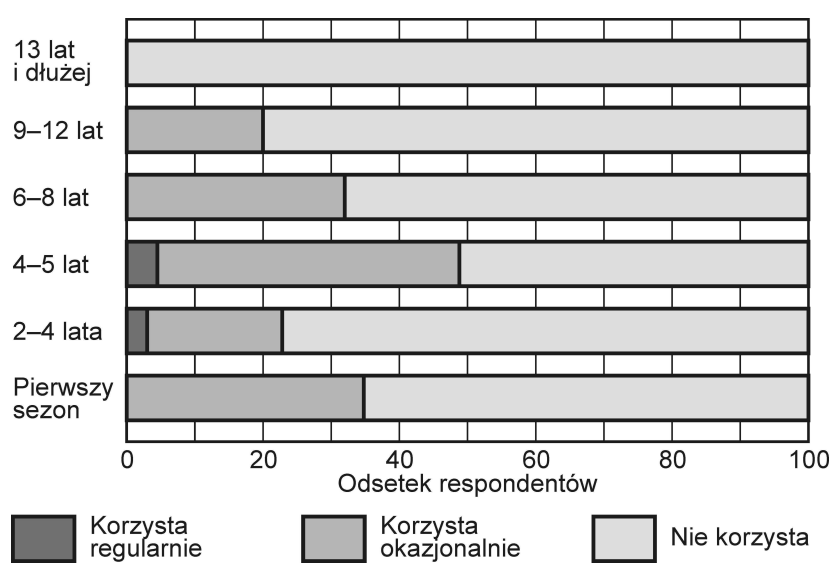

Rys. 7. Staż uprawiania skituringu a korzystanie z usług przewodnika przez respondentów

Wśród klientów przewodników górskich znaleźli się respondenci o zróżnicowanym doświadczeniu. Ważną grupę stanowiły osoby początkujące, uczące się na kursach skiturowych. Większy był jednak odsetek osób mających już kilkuletnie doświadczenie, a mimo to korzystających z usług przewodnika. Niektórzy uczestniczyli nawet regularnie w kilkudniowych wycieczkach narciarskich w Tatrach czy w Alpach.

Ponadto prawie każdy z badanych ukończył jeden lub kilka kursów związanych z aktywnością górską. Najpopularniejsze wśród nich były kursy "lawinowe” $(42 \%)$, co jest dobrą tendencją dla podniesienia świadomości zagrożeń spowodowanych przez masy śniegu w górach. Nieco mniejszą popularnością wśród ankietowanych (35\%) cieszyły się kursy podstaw wspinaczki na skałach organizowane latem. Przydatność technicznych umiejętności nie jest zbyt duża podczas tradycyjnych wycieczek skiturowych, jednak przy uprawianiu skialpinizmu, pokonywaniu lodowców czy przekraczaniu skalnych grani może się okazać istotna. Około $1 / 3$ badanych ukończyła specjalistyczny kurs skiturowy lub turystyki zimowej, a niewielka grupa taternicki kurs zimowy wspinaczkowy. Były to najczęściej osoby o bardzo wysokich umiejętnościach i wiedzy.

\subsection{BEZPIECZEŃSTWO TURYSTÓW}

Skituring uprawiany jest w górach, poza szlakami, w warunkach zagrożenia, np. lawinami, i nie należy do bezpiecznych form turystyki kwalifikowanej. Temat ten jest poruszany w literaturze naukowej, dlatego był przedmiotem zainteresowania również w przypadku niniejszego artykułu. Wypadki i kontuzje w czasie uprawiania skituringu zdarzyły się u 13\% ankietowanych, z czego u 3\% były to poważne wypadki, a pozostałe $10 \%$ respondentów doznało drobnych urazów. Wspomniane 3\% osób po poważnych urazach, to duży odsetek w porównaniu z uczestnikami innych form aktywnego wypoczynku, nawet zaliczanych do niebezpiecznych. Uzasadnione jest więc poznanie poziomu przygotowania uprawiających skituring, w tym wiedzy i umiejętności respondentów w zakresie bezpieczeństwa na stoku. Wiedza narciarzy skiturowych na temat zagrożeń górskich jest zapewne znacznie wyższa niż przeciętnych turystów spotykanych na terenie Tatr. Liczne skończone kursy (np. kursy „lawinowe” ukończyło 42\%) świadczą, że badani są świadomi konieczności podnoszenia górskich kwalifikacji. Warto jednak zaznaczyć, że skituring to dyscyplina niezwykle wymagająca. Sama wiedza nie wystarcza, jeśli nie jest ona stosowana w praktyce. Nawet osoby o dużym doświadczeniu bez powodu lekceważą podstawowe zasady bezpieczeństwa, co skutkuje często wypadkami czy urazami. Wiele osób zjeżdża żlebami przy niestabilnej pokrywie śnieżnej, pomimo ostrzeżeń TOPR. Nawet przewodnikom górskim zdarza się wchodzić na zamarznięte stawy późną wiosną, co wiąże się ze znacznym ryzykiem załamania się tafli lodowej. Oprócz przestrzegania określonych zasad konieczne są ciągłe ćwiczenia praktyczne, np. w zakresie poszukiwania osób zasypanych śniegiem za pomocą detektora lawinowego lub hamowania upadku na stromym stoku. W sytuacji zagrożenia tylko odruchowe, wyuczone reakcje mogą okazać się skuteczne. W środowisku narciarskim oraz w ogóle turystów górskich widoczna jest tendencja do poszerzania własnej wiedzy i umiejętności, więc można mieć nadzieję, że liczba wypadków będzie się zmniejszać.

Ocena wiedzy i umiejętności respondentów na temat bezpieczeństwa i pierwszej pomocy w skali od 1 do 5 wahała się od 2 do prawie 4 . W badaniach zdarzało się, że osoba początkująca deklarowała wysoki poziom umiejętności, a przewodnik górski z wielolet- 
nim doświadczeniem określał swój poziom wiedzy jako przeciętny. Fakty te wynikały nie tylko $\mathrm{z}$ chęci przedstawienia własnej osoby w lepszym świetle, ale przede wszystkim $\mathrm{z}$ nieświadomości pewnych zagrożeń, jakie można spotkać w górach.

Najlepiej oceniano własną umiejętność jazdy na nartach (rys. 8). Dobre umiejętności jazdy na nartach można potwierdzić na podstawie regularnych śladów nart pozostawianych na obserwowanych stokach w trakcie badań terenowych. Większość ankietowanych sprawnie poruszała się $\mathrm{w}$ terenie wysokogórskim.

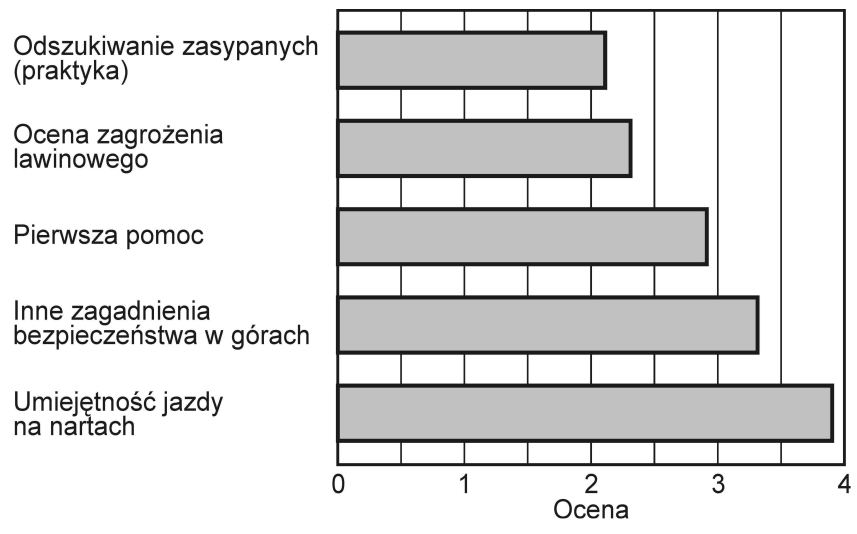

Rys. 8. Ocena stanu własnej wiedzy i umiejętności w zakresie bezpieczeństwa $\mathrm{w}$ uprawianiu skituringu

Niestety problem zagrożenia lawinowego jest jeszcze za mało uwzględniany przez respondentów. Prawie $40 \%$ ankietowanych nie posiadało detektora lawinowego - niezbędnego urządzenia, służącego odszukaniu osób zasypanych pod śniegiem. Tak mała popularność detektorów związana jest z ich wysoką ceną oraz nieświadomością turystów co do konieczności ich posiadania oraz $\mathrm{z}$ lekceważeniem tematu zagrożeń lawinowych. Na szczęście popularność detektorów ciągle rośnie, a producenci wprowadzają coraz doskonalsze i prostsze $\mathrm{w}$ obsłudze urządzenia; można je też wypożyczyć. Kilka lat temu tylko nieliczne osoby posiadały detektor lawinowy, a obecnie już ponad połowa respondentów przyznała, że je używa. Kilku respondentów nie posiadało detektora, ale korzystało z usług wypożyczalni sprzętu lawinowego. Daleko jeszcze Polakom do francuskich turystów górskich, którzy w 95\% są wyposażeni w tzw. trio (detektor, łopata i sonda), a równocześnie posiadających telefon komórkowy jako sposób przekazywania alertu do służb ratunkowych, przeceniany jako dający wrażenie (zbyt) ważnego sprzętu dla bezpieczeństwa (VALAT, RAVANEL 2013). Również szwedzkie badania potwierdzają, że $11 \%$ narciarzy nie korzysta z urządzeń bezpieczeństwa, a $87 \%$ używa takich sprzętów regularnie.

\section{WNIOSKI}

Jak dalece współcześnie uprawiany skituring odbiega od „wyryp" narciarskich z czasów J. Oppenheima (początek XX w.) - niełatwo odpowiedzieć. Można przypuszczać, że takie cechy, jak wytrzymałość, samodzielność, orientacja $\mathrm{w}$ terenie, zaradność wobec niebezpieczeństw i trudności są nadal niezbędnymi cechami uprawiających tę formę turystyki. Autor ten wskazał na aktywny wypoczynek i relaks $(71 \%)$, dbanie o zdrowie i kondycję fizyczną (49\%), a także chęć sprawdzenia swoich możliwości (31\%) jako główne motywy uprawniania skituringu.

Przeprowadzone badania pozwalają stwierdzić, że skituring występuje w Polsce, ale jest turystyką niszową uprawianą głównie w Tatrach, w mniejszym stopniu $\mathrm{w}$ pozostałych pasmach górskich (Beskidach, Sudetach). Uprawia ją specyficzna grupa turystów, której nie można uznać za typową dla Polski. Przede wszystkim wyróżniają się oni wysokim poziomem wykształcenia ( $74 \%$ - wyższe, $26 \%$ - średnie i policealne), młodym wiekiem (19-45 lat - około 90\% badanych) oraz zawodem, głównie intensywną pracą umysłową (informatyk, inżynier, lekarz, finansista, manager, student, wolny zawód, własna działalność gospodarcza). Grupa zdominowana jest przez mężczyzn (88\%) i są to osoby dbające o kondycję fizyczną oraz zdrowie, które regularnie przez cały rok uprawiają rekreację ruchową, głównie na świeżym powietrzu w kontakcie z przyrodą. Duża grupa respondentów zarabia powyżej mediany dla Polski i inwestuje w specjalistyczny sprzęt narciarski.

$\mathrm{W}$ większości (75\%) są to osoby pochodzące $\mathrm{z}$ województw południowej Polski, na terenie których znajdują się pasma górskie Sudetów i Karpat - dominują mieszkańcy województwa małopolskiego $(41 \%)$ i śląskiego $(26 \%)$. Aż $81 \%$ przyjeżdża z miast, przeważaja wśród nich (54\%) osoby $\mathrm{z}$ dużych miast, liczących ponad 100 tys. mieszkańców (głównie z Krakowa, w mniejszym stopniu Warszawy oraz Łodzi, Wrocławia, Poznania). W skituringu odnajdują się osoby (głównie mężczyźni), które po pracy umysłowej relaksują się poprzez kontakt z przyrodą, chcące sprawdzać własne możliwości i zaznawać nowych wrażeń Ważna jest dla nich nie tylko kondycja, ale także dalsze pogłębianie wiedzy i umiejętności z zakresu skituringu, wspinaczki i narciarstwa. Większość z nich wykazywała wysokie umiejętności w jeździe na nartach. Skiturowcy korzystają z kursów i wycieczek prowadzonych przez doświadczonych przewodników w kraju i za granicą. Niektórzy próbują swych sił w zawodach skialpinistycznych, co może świadczyć o ich wysokich ambicjach.

Prawie 100 lat od prowadzonych przez J. Oppenheima badań i obserwacji można $\mathrm{z}$ pewnością stwier- 
dzić, że współczesny turysta jest lepiej wyposażony w specjalistyczny sprzęt (buty, narty, foki i inne), ma możliwość skorzystania $\mathrm{z}$ detektorów lawinowych (urządzenia służącego odszukaniu osób zasypanych pod śniegiem), a także $z$ innych pomocnych urządzeń, np. telefonu komórkowego. Ponadto turysta, który ma dostęp do Internetu, może uzyskać szczegółowe dane pogodowe w czasie rzeczywistym oraz śledzić opinie innych skiturowców na temat warunków pogodowych. Daje mu to większe poczucie bezpieczeństwa w razie wypadku, co niestety nie przekłada się na ich brak.

\section{PRZYPIS}

${ }^{1} \mathrm{~W}$ pracy wykorzystano badania mgr. Piotra BARTOCHOWSKIEGO (2011), absolwenta kierunku "turystyka i rekreacja” Uniwersytetu Łódzkiego.

\section{BIBLIOGRAFIA}

ADAMCZYK J., 2009, Skituring w polskich górach - nowy produkt turystyczny?, „Studia i Materiały Centrum Edukacji Przyrodniczo-Leśnej", 11(4 [23]), s. 311-317.

BARTOCHOWSKI P., 2011, Rozwój skitouringu w Tatrach polskich, mps pracy magisterskiej wykonanej pod kier. prof. I. Jażdżewskiej w IGMiT WNG UŁ.

BERBEKA J., 2015, Determinanty uprawiania skitouringu w rejonach arktycznych, [w:] Turystyka sportowa. Spoteczno-kulturowy potencjat i perspektywy rozwoju, M. Kazimierczak (red.), AWF w Poznaniu, Poznań, s. 138-151.

BIELAŃSKI M., 2010, Ruch narciarzy wysokogórskich w Tatrzańskim Parku Narodowym, „Folia Turistica”, 22, s. 185-205.

BRANIGAN H., JENNS K., 2006, A complete guide to ski touring and ski mountaineering, Author House, Bloomington.

FREULER B., HUNZIKER M., 2007, Recreation activities in protected areas: bridging the gap between the attitudes and behaviour of snowshoe walkers, „,Forest Snow and Landscape Research", 81(1/2), s. 191-206.

GACEU O., ZARRILLI L., GONZER M., POP A.C., 2015, Snow cover in support of development of winter tourism activities in Muntele Băișorii resort, "GeoSport for Society”, 2, 1, s. 7-20.
HARSHAW H.W., SHEPPARD S.R.J., 2004, Assessing timber harvesting impacts to recreation in areas adjacent to parks and protected areas: an example from British Columbia, Collaborative for Advanced Landscape Planning, Faculty of Forestry, University of British Columbia.

HARVEY S., ZWEIFEL B., 2008, New trends of recreational avalanche accidents in Switzerland, Proceedings ISSW 2008, International Snow Science Workshop, Whistler BC, Canada, 21-27 September 2008.

KNOPP T.B., TYGER J.D., 1973, A study of conflict in recreational land use: snowmobiling vs. ski-touring, "Journal of Leisure Research", 5(3), s. 6-17.

OPPENHEIM J., 1936, Szlaki narciarskie Tatr polskich, PZN, Kraków.

PHILIPP R., 2010, Czy narciarstwo wraca do korzeni? Rzecz o filozofii narciarstwa, „Studia Humanistyczne”, 10, Akademia Wychowania Fizycznego w Krakowie, s. 73-86.

SCHWEIZER J., LÜTSCHG M., 2001, Characteristics of human-triggered avalanches, "Cold Regions Science and Techno$\log y^{\prime \prime}, 33(2)$, s. 147-162.

TECHEL F., ZWEIFEL B., WINKLER K., BAUR R., 2014, Patterns of Recreational Backcountry Usage - Analyzing Data from Social Media Mountaineering Networks and Avalanche Statistics, Proceedings, International Snow Science Workshop, Banff, s. $1148-1152$.

THAPA B., GRAEFE A.R., 2004, Recreation conflict and tolerance among skiers and snowboarders, ,Journal of Park and Recreation Administration", 22(1), s. 37-52.

VASKE J., DYAR R., TIMMONS N., 2004, Skill level and recreation conflict among skiers and snowboarders, "Leisure Sciences”, 26(2), s. $215-225$.

WeISS R., 1983, Touren-Skilauf. Sicher und Genußvoll in Pulver und Firn, Steiger Verlag, Insbruck.

WITKOWSKI, Z., MROCZKA A., ADAMSKI P., BIELAŃSKI M., KOLASIŃSKA A., 2010, Nielegalna dyspersja turystów - problem parków narodowych i rezerwatów przyrody w Polsce, „Folia Turistica", 22, s. 35-65.

http://stat.gov.pl/cps/rde/xbcr/gus/KTS_Uczestnictwo_pol _w_sporcie_w_2012.pdf.

www.bergportal.ch; 15.05.2011.

www.camptocamp.org; 15.05.2011.

www.national-geographic.pl/traveler/adventure/samotni-wsniegu; 15.05.2011.

www.skitury.fora.pl; 15.05.2011.

www.wynagrodzenia.pl; 15.05.2011.
Artykuł wpłyną: 12 lutego $2016 \mathrm{r}$ Zaakceptowano do druku: 14 czerwca $2016 \mathrm{r}$. 